\title{
PENGARUH ASOSISASI MEREK TERHADAP RESPON KONSUMEN MEREK TOLAK ANGIN DI SURABAYA
}

\author{
Iwan Purnomo Adi \\ Sekolah Tinggi Ilmu Ekonomi Yayasan Palapa Nusantara Surabaya \\ Email: iwanpurnomoadi@yahoo.com \\ http://doi.org/10.21107/pmt.v11i2.4769
}

\begin{abstract}
Abstrak
Fokus penelitian ini adalah menganalisa pengaruh asosiasi merek terhadap respon konsumen. Dalam penelitian ini, asosiasi merek diukur melalui fungsi merek (garansi, identifikasi pribadi, identifikasi sosial dan status). Dilain pihak respon konsumen diukur melalui kemauan membayar dengan harga premium, merekomendasikan ke orang lain, dan menerima perluasan merek. Sampel penelitian ini merupakan responden konsumen yang mengkonsumsi Tolak Angin di Surabaya. Ada 385 responden konsumen yang digunakan untuk keperluan pelaksanaan penelitian ini. Data yang diperoleh dianalisa dengan menggunakan program SPSS 13.0. Program SPSS digunakan untuk keperluan untuk menjalankan teknik analisa statistik yang bernama korelasi kanonikal. Hasil penelitian menunjukan bahwa asosiasi merek sebagai garansi asosiasi merek sebagai identifikasi , asosiasi merek sebagai identifikasi sosial, asosiasi merek sebagai status mempunyai pengaruh pada 2 respon konsumen (hipotesis diterima).
\end{abstract}

Kata Kunci : asosiasi merek, respon konsumen, garansi, identifikasi personal, identifikasi sosial, status

\section{PENDAHULUAN}

Produk merupakan sesuatu yang dibuat di pabrik, tetapi merek adalah hal yang sesungguhnya dibeli oleh pelanggan (Susanto, 2006). Merek berfungsi untuk mengingatkan, sumber informasi bagi konsumen, serta membedakan satu produk dengan produk yang lain. Saat melihat atau mendengar nama atau simbol merek, dapat timbul tautan dalam ingatan konsumen mengenai kualitas, harga, citra dan apapun terkait dengan merek. Tautan dalam ingatan mengenai karakteristik merek tersebut merupakan asosiasi merek. Pettis (1995) menyatakan bahwa asosiasi merek merupakan atribut yang dihubungkan dengan merek oleh konsumen.

Aaker (1991) menjelaskan bahwa asosiasi merek bermanfaat bagi konsumen dan pemasar. Konsumen menggunakan asosiasi merek untuk membantu memproses, mengorganisasi, dan mendapatkan kembali informasi dalam ingatan. Asosiasi merek juga dapat membantu konsumen dalam membuat keputusan membeli. Di sisi lain, pemasar menggunakan asosiasi merek untuk membedakan atau memposisikan mereknya dibanding kompetitor, mengembangkan merek, mengingatkan akan benefit atau keuntungan membeli atau menggunakan merek, menciptakan sikap dan perasaan positif terhadap merek.

Penggunaan asosiasi merek sebagai alat bagi pemasar merupakan strategi yang menguntungkan. Aaker (1991) menjelaskan bahwa asosiasi merek dapat membuat merek menjadi kuat. Kekuatan merek yang berada di benak konsumen dibangun melalui asosiasi merek menyebabkan persepsi, citra, perasaan dan perilaku konsumen terhubung (in line / connected) dengan merek tersebut (Durianto, 2005). Hal ini menyebabkan penggunaan brand atau merek menjadi salah satu kekuatan bisnis yang harus dimiliki produsen.

Upaya produsen dalam meningkatkan 
kekuatan merek di temukan pada produsen jamu merek Tolak Angin dari PT. Sido Muncul. Ada tiga cara yang digunakan PT. Sido Muncul yaitu pertama mengkomunikasikan produk Tolak Angin sebagai produk herbal modern dengan menggunakan proses produksi, mesin dan standard pembuatan obat modern, kedua menggunakan endorser tokoh tokoh publik, akademisi, dokter, atlit, pemain film, dan musisi dan ketiga menggunakan tagline" Orang Pintar Minum Tolak Angin." Penggunaan mesin dan standard pembuatan obat modern bertujuan untuk merubah kualitas dan citra jamu yang dibuat dengan cara tradisional. Mesin modern membuat produk Tolak Angin tidak memiliki residu atau endapan seperti jamu pada umumnya dan membuat jamu mudah di konsumsi tanpa harus diseduh terlebih dahulu. Pemilihan endorser berbeda dari produsen jamu pada umumnya merupakan langkah linier untuk membangun persepsi "pintar". Produsen jamu pada umumnya menggunakan komedian atau penyanyi dangdut dengan pertimbangan lebih sesuai dengan segmen produk jamu. Adapun dengan tagline "Orang Pintar Minum Tolak Angin" , PT. Sido Muncul berusaha meyakinkan konsumennya bahwa keputusan dalam memilih merek Tolak Angin adalah keputusan yang pintar. karena proses dan penggunaan teknologi modern dan direkomendasi orang "pintar". Tiga upaya PT. Sido Muncul tersebut diharapkan agar asosiasi konsumen terhadap merek dapat menimbulkan respon yang positif bagi produknya.

Del Rio et.al (2001) menyatakan bahwa asosiasi merek dapat muncul dalam benak kosumen melalui empat dimensi asosiasi merek yaitu asosiasi merek sebagai garansi; asosasi merek sebagai identifikasi personal; asosasi merek sebagai identifikasi sosial dan asosasi merek sebagai status. Disisi lain, respon konsumen mengacu pada niat (intention) konsumen. Niat (intention) diwujudkan dalam kesediaan konsumen untuk membayar dengan harga premium dan kesediaan konsumen memberikan rekomendasi ke pihak lain.
Berdasarkan latar belakang diatas maka pada penelitian ini, peniliti akan mencari tahu empat dimensi asosiasi merek konsumen dan respon konsumen terhadap merek Tolak Angin di Surabaya, dengan mengangkat beberapa rumusan masalah penelitian sebagai berikut: apakah terdapat pengaruh asosiasi merek sebagai garansi, asosiasi merek sebagai identifikasi personal, asosiasi merek sebagai identifikasi sosial, asosiasi merek sebagai status terhadap respon konsumen berupa kesediaan konsumen Tolak Angin di Surabaya untuk merekomendasikan merek serta membayar dengan harga premium. Sesuai dengan rumusan masalah yang diangkat maka pada penelitian digunakan penelitian kausal yang bertujuan untuk mencari tahu pengaruh empat dimensi asosiasi merek terhadap respon konsumen berupa kesediaan konsumen Tolak Angin di Surabaya untuk merekomendasikan merek serta membayar dengan harga premium.

Penelitian ini menggunakan model yang dibangun oleh del Rio et.al (2001) yang menyatakan bahwa asosiasi merek sebagai garansi; asosasi merek sebagai identifikasi personal; asosasi merek sebagai identifikasi sosial dan asosasi merek sebagai status berpengaruh pada respon konsumen untuk membayar dengan harga premium dan kesediaan konsumen memberikan rekomendasi ke pihak lain.

Berdasarkan rumusan masalah dan landasan teori yang telah dibangun, maka dirumuskan hipotesis penelitian sebagai berikut: asosiasi merek sebagai garansi, asosiasi merek sebagai identifikasi personal, asosiasi merek sebagai identifikasi sosial, dan asosiasi merek sebagai status berpengaruh pada respon konsumen berupa kesediaan konsumen Tolak Angin di Surabaya untuk merekomendasikan merek serta kesediaan konsumen Tolak Angin di Surabaya untuk membayar harga premium. 


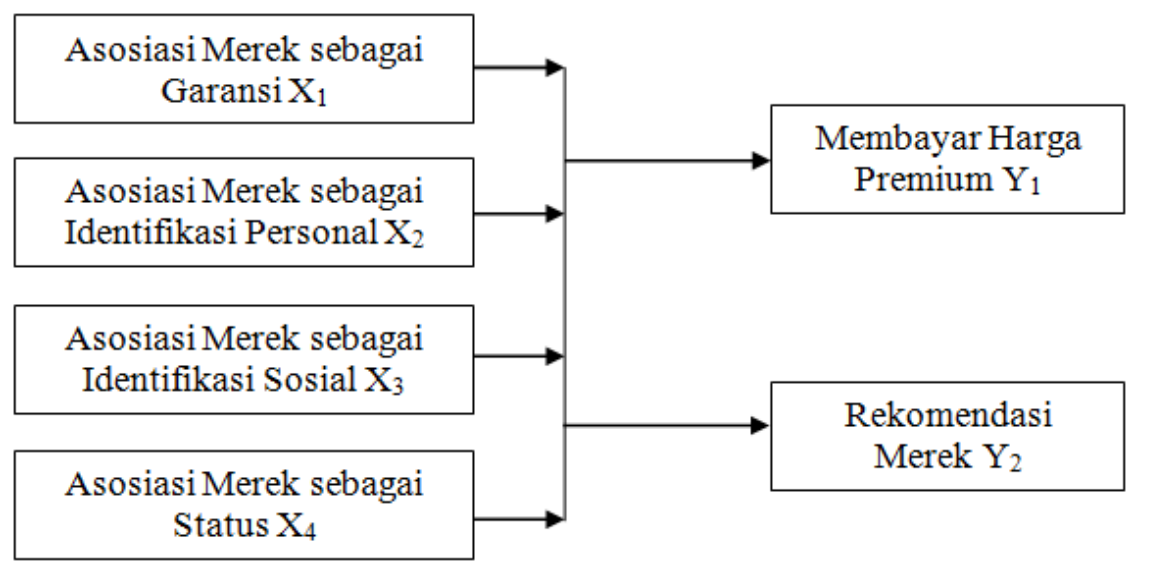

\section{METODOLOGI}

\section{- Penentuan Sample}

Penelitian ini bertujuan untuk mengetahui pengaruh variabel asosiasi merek terhadap variabel respon konsumen. Berdasarkan pertimbangan di atas, maka penelitian ini menggunakan pendekatan penelitian kuantitatif, yaitu penelitian yang bertujuan melakukan pengujian hipotesis.

Dalam penelitian ini populasi adalah pembeli dan pengguna Tolak Angin yang ada di Surabaya. Pengambilan sampel dilakukan dengan metode accidental sampling. Pertimbangan penentuan jumlah sampling didasarkan pada jumlah populasi yang infinite (tidak diketahui jumlah pastinya). Dengan derajat kepercayaan $95 \%$ maka minimal sampel yang harus disediakan dalam penelitian ini adalah sebanyak 385 responden. Metode pengumpulan data yang digunakan dalam penelitian ini adalah melalui: Survei langsung dengan metode kuesioner.

\section{- Uii Validitas}

Uji validitas dilakukan dengan cara mencari koefisien product moment ( $\mathrm{r}$ ), dan dibandingkan dengan angka krisis $r$ yang dapat diperoleh dengan jalan melihat tabel. Untuk menguji reliabilitas suatu instrumen dilakukan dengan cara menghitung koefisien Alpha Cronbachnya untuk mengetahui reliabilitas skala pengukurannya.

Penelitian ini bersifat causal research. Teknik analisis yang dipakai dalam penelitian ini adalah Canonical
Correlations yang dapat mengeksplor secara bersama-sama multiple dependent variabel dari multiple independent variabel. Dalam analisa ini, canonical loading berfungsi dapat mengintepretasikan hubungan antara variabel dengan canonical variate. Pengujian dilakukan dengan menggunakan uji canonical loading pada nilai signifikan probabilitas canonical loading di atas koefisien $\alpha=0,05$ sedangkan $\mathrm{HO}$ akan ditolak ketika nilai signifikan probabilitas canonical loading berada dibawah koesifien $\alpha=0,05$.

Beberapa asumsi dalam menerapkan Canonical Correlation antara lain adalah Multikolinieritas, Heteroskedastisitas melalui pendekatan metode Rank Spearman, Normalitas digunakan uji statistik Kolmogorov-Smirnov (KS), dan Linearitas dengan uji Lagrange Multiplier.

Adapun tahapan dalam Analisa Canonical Correlation adalah sebagai berikut: menetapkan sasaran canonical correlation. mengembangkan rencana analisa. menguji asumsi yang mendasari canonical correlation. menentukan model kanonik dan menguji kesesuaian model. Setelah 3 kriteria di atas telah terpenuhi, langkah selanjutnya adalah mengintepretasikan canonical function, Sama seperti teknik multivariate lainnya, analisa canonical correlation harus melalui proses validasi untuk memastikan hasil yang didapat tidak hanya spesifik pada data sampel. 


\section{HASIL PEMBAHASAN}

- Validitas dan Reliabilitas

Uji validitas menunjukkan setiap indikator variabel menunjukkan nilai koefisien korelasi $r$ diatas angka kritik tabel korelasi nilai $r$ sebesar 0,3061 . Uji reliabilitas masing-masing variabel yang diukur menunjukkan nilai Alpha lebih besar dari 0,6 maka item pengukuran dinyatakan reliable.

\section{- Asumsi Pengqunaan Model}

Uji multikolinieritas menunjukkan Variance Inflation Factor (VIF) dari semua variabel independen $\square$ yaitu memperlihatkan nilai lebih kecil dari 10, hal ini berarti bahwa tidak terdapat gejala multikolinieritas., Uji heteroskedaktisitas, nenunjukkan korelasi lebih besar dari 0,05 (5\%) atau tidak signifikan, hal ini berarti bahwa tidak terjadi heteroskedastis yang tidak dapat ditolerir dalam model regresi yang terbentuk. Uji Normalitas menujukkan nilai signifikansi hasil uji Kolmogorov-Smirnov (KS) yang pada model regresi yang terbentuk menunjukkan nilai sebesar 0,491 untuk pola hubungan $\mathrm{X} \square \mathrm{Y}$ 1, sedangkan untuk pola hubungan $\mathrm{X} \square \mathrm{Y} 2$ memiliki nilai signifikansi hasil uji Kolmogorov-Smirnov (KS) sebesar 0,086 . Dari angka tersebut dapat diketahui bahwa masing-masing nilai signifikansi hasil uji Kolmogorov-Smirnov (KS) lebih besar dari 0,05 (5\%), hal ini memberikan indikasi bahwa residual model regresi yang dibentuk berdistribusi normal. Uji Linearitas menunjukkan uji Lagrange Multiplier hasil perhitungan Chi Square untuk pola hubungan kuadratis dalam penelitian ini yakni $\mathrm{X} 2 \square \mathrm{Y} 1$ sebesar 154,385 (lebih kecil dari Tabel $=424,334$ ) dan hubungan $\mathrm{X} 2 \square \mathrm{Y} 2$ sebesar 119,350 (lebih kecil dari Tabel $=424,334)$. Hasil ini menunjukkan bahwa hubungan $\mathrm{X} \square \mathrm{Y} 1$ dan $\mathrm{X} \square \mathrm{Y} 2$ lebih bersifat linier.

\section{- Estimasi Canonical Function}

Hasil Uji Eigen-Values dan Korelasi Kanonikal dalam menunjukkan bahwa canonical correlation yang dihasilkan adalah sebesar 0,722 dengan eigenvalues di atas nilai 1 ada 1 yaitu 1,088 dan tingkat signifikasi sebesar
0,000 sehingga secara individu hanya ada 1 canonical function yang layak untuk diinterpretasikan. Sementara fungsi kanonikal lainnya tidak dapat dianalisa lebih lanjut karena nilai eigenvalues-nya dibawah 1. Hasil uji fungsi kanonikal secara bersama sama dengan menggunakan Pillais, Hotelings, Wilks dan Roys dan menunjukan nilai signifikasi yang lebih kecil dari 0,05 (5\%) dengan demikian secara bersama sama fungsi kanonikal 1 dan 2 adalah signifikan sehingga dapat diproses lebih lanjut. Meskipun secara bersama sama kedua fungsi kanonikal dinyatakan signifikan, namun pada fungsi kanonikal ke 2 terdapat korelasi kanonikal yang lemah yaitu 0,145 Untuk itu hanya fungsi kanonikal pertama yang akan dianalisis lebih lanjut. Fungsi kanonikal pertama dipilih karena signifikan secara individu dan bersama sama mempunyai nilai korelasi kanonikal yang tinggi. Dengan demikian kumpulan variabel independen dengan kumpulan variabel dependen dapat dinyatakan mempunyai hubungan yang kuat sehingga layak untuk dianalisa lebih lanjut. Nilai Redundancy Index fungsi kanonikal pertama menunjukkan nilai Redundancy

Index sebesar 0,349 untuk variabel dependen dan 0,447 untuk variabel independen. Sedangkan untuk fungsi kanonikal kedua menunjukkan nilai Redundancy Index sebesar 0,007 untuk variabel dependen dan 0,008 untuk variabel independen. Artinya dengan menggunakan Redundancy Index dapat dipastikan bahwa fungsi kanonikal pertama lebih mampu menjelaskan variansi yang terjadi antara hubungan variabel dependen dengan variabel independen.

\section{- Interpretasi Canonical Function}

Interpretasi Canonical Weigh atau standardized coefficient dari fungsi kanonikal pertama menunjukkan, variabel asosiasi merek sebagai status adalah variabel yang paling besar yaitu 0,563 dalam memberikan kontribusinya terhadap variabel respon konsumen berupa kesediaan untuk membayar dengan harga premium dan merekomendasikan kepada 
pihak lain. Sedangkan untuk variabel dependen yaitu respon konsumen diketahui bahwa nilai korelasi variabel kesediaan untuk membayar dengan harga premium untuk kesediaan untuk membayar dengan harga premium mendapatkan kontribusi besar dari variabel asosiasi merek dengan nilai Canonical Weight sebesar 0,686.

Interpretasi Canonical Loading atau canonical structure fungsi kanonikal pertama ditemukan bahwa seluruh variabel independen mempunyai nilai korelasi yang lebih besar dari 0,5, untuk itu asosiasi merek mempunyai hubungan yang kuat terhadap respon konsumen. Adapun variabel dependen memiliki nilai Canonical loading untuk semua variabel mempunyai nilai korelasi yang lebih besar 0,5, sehingga dapat dikatakan mempunyai hubungan yang kuat.

\section{- Validasi Canonical Function}

Uji Validasi Fungsi Kanonikal Metode Split diketahui bahwa semua besaran analisis korelasi kanonikal menunjukkan kecenderungan karakteristik yang sama. Hal ini ditunjukan dengan nilai EigenValue antara persamaan kanonikal split 1 dengan persamaan kanonikal split 2. Nilai Eigen-Value yang didapatkan adalah sebesar 1,182 untuk persamaan kanonikal split 1dan nilai Eigen-Value sebesar 1,035 persamaan kanonikal split 2. Fakta ini menunjukkan tingkat konsisitensi dari korelasi kanonikal dalam menjelaskan hubungan kausalitas yang dibentuk antara asosiasi merek dengan respon konsumen.

\section{- Uji Hipotesis}

Nilai canonical loading sebesar 0,689 mencerminkan korelasi covariate (X1) dengan variabel kanonikal $(X)$ yang dapat diterima (loading $>0,500$ ) dan signifikan (di atas nilai korelasi (r) kritis sebesar 0,1045). Sedangkan nilai korelasi kanonikal sebesar 0,722 dengan nilai eigenvalues 1,088 (eigenvalues di atas nilai 1). Nilai canonical loading sebesar 0,558 mencerminkan korelasi covariate (X2) dengan variabel kanonikal $(X)$ yang dapat diterima (loading $>0,500$ ) dan signifikan (di atas nilai korelasi (r) kritis sebesar 0,1045). Sedangkan nilai korelasi kanonikal sebesar 0,722 dengan nilai eigenvalues 1,088 (eigenvalues di atas nilai 1). Nilai canonical loading sebesar 0,653 mencerminkan korelasi covariate (X3) dengan variabel kanonikal $(\mathrm{X})$ yang dapat diterima (loading $>0,500$ ) dan signifikan (di atas nilai korelasi (r) kritis sebesar 0,1045). Sedangkan nilai korelasi kanonikal sebesar 0,722 dengan nilai eigenvalues 1,088 (eigenvalues di atas nilai 1). Nilai canonical loading sebesar 0,709 mencerminkan korelasi covariate (X4) dengan variabel kanonikal $(X)$ yang dapat diterima (loading $>0,500$ ) dan signifikan di atas nilai korelasi (r) kritis sebesar 0,1045. Sedangkan nilai korelasi kanonikal sebesar 0,722 dengan nilai eigenvalues 1,088 (eigenvalues di atas nilai 1 ).

Kenyataan ini menegaskan bahwa asosiasi merek sebagai status (X4) memberikankontribusi yang signifikan terhadap terbentuknya respon konsumen yang dicerminkan dengan kesediaan konsumen untuk membayar dengan harga premium dan merekomendasikan ke orang lain. Berdasarkan hasil uji canoninal corelation diatas maka hipotesis penelitian yaitu "asosiasi merek sebagai garansi, sebagai identifikasi personal, sebagai identifikasi sosial, dan status berpengaruh pada respon konsumen berupa kesediaan konsumen Tolak Angin di Surabaya untuk merekomendasikan merek serta kesediaan konsumen untuk membayar harga premium dapat diterima atau dapat dibuktikan kebenarannya.

Berdasarkan hasil pengujian hipotesis dapat diketahui bahwa variabel asosiasi merek sebagai garansi berpengaruh pada kesediaan konsumen untuk membayar dengan harga premium dan merekomendasikan ke orang lain. Dari sini tampak bahwa pada benak konsumen, jaminan akan kualitas yang diberikan oleh merek jamu Tolak Angin mulai terbentuk. Hal ini dapat disebabkan karena konsumen semakin peka terhadap produk jamu yang tidak herbal atau jamu yang diproduksi dengan menggunakan bahan-bahan kimia buatan (sintetik) dan tidak higienis. Dengan demikian ketika produsen Tolak Angin menawarkan produknya sebagai produk 
yang herbal dan alami maka konsumen merespon dengan positif.

Hal ini berarti bahwa jaminan akan kualitas merek Tolak Angin telah dirasakan konsumen. Menurut Hutton (1997), ketika persepsi akan garansi atau jaminan akan kualitas tinggi maka persepsi tersebut akan menimbulkan evaluasi merek yang lebih disukai dan membuat konsumen mau membayar dengan harga premium. Berdasarkan definisi tersebut, dapat dikatakan bahwa konsumen cenderung membayar dengan harga premium ketika merek menawarkan kualitas yang dinginkan oleh konsumen.

Jika dilihat yang terjadi pada merek Tolak Angin, beberapa tahun belakang ini produsen Tolak Angin semakin sering memperkenalkan produk herbal dengan segala kelebihannya, memperlihatkan alat alat produksi yang modern dan melakukan uji uji kekhasiatan dan toksin. Hal ini mempengaruhi asosiasi konsumen terhadap merek Tolak Angin sebagai merek yang menawarkan jaminan kualitas yang sesuai dengan keinginan konsumen.

Dari hasil pengujian dapat diketahui bahwa variabel asosiasi merek sebagai identifikasi personal berpengaruh pada kesediaan konsumen untuk membayar dengan harga premium dan merekomendasikan ke orang lain. Dari hasil analisa juga diketahui bahwa asosiasi merek sebagai identifikasi personal juga mulai terbentuk pada ingatan konsumen Tolak Angin. Ini berarti bahwa merek Tolak Angin mulai dapat dipakai sebagai cerminan identitas diri konsumennya.

Hal ini juga didukung dari hasil penelitian dilapangan dari responden Tolak Angin yang menunjukan rata rata responden memberikan skala yang tinggi untuk indikator Tolak Angin mencerminkan individu yang memiliki gaya hidup praktis dan yang memiliki gaya hidup modern. Para responden memberikan komentar bahwa mereka suka menggunakan merek Tolak Angin karena karena jamu Tolak Angin disajikan dalam bentuk sachet yang mudah dibawa kemana-mana dan yang jelas instan sesuai dengan gaya hidup moderen yang serba sibuk. Hal ini ditunjang oleh penyampaian pesan secara itensif melalui iklan yang menampilkan personifikasi orang-orang moderen jauh dari kesan tradisional, yang kemudian hal ini secara perlahan terkonstruksi dalam benak konsumen sehingga lahir kesan emosional yang menganggap bahwa produk jamu Tolak Angin sangat sesuai dengan gaya hidup modern. Westbrook , 1987 seperti yang dikutip Del Rio et.al (2001) menyatakan bahwa konsumen yang mengasosiasikan merek dengan pengalaman emosional memiliki kecenderung untuk merekomendasikan merek kepada pihak lain. Semakin tinggi ketertarikan dan identifikasi personal konsumen terhadap merek maka semakin tinggi motivasinya untuk merekomendasikan merek tersebut, berpengaruh positif untuk menerima ekstensi merek dan menerima harga premium.

Dari hasil pengujian dapat diketahui bahwa variabel asosiasi merek sebagai identifikasi sosial berpengaruh pada kesediaan konsumen untuk membayar dengan harga premium dan merekomendasikan ke orang lain. Ini berarti bahwa lingkungan sosial mempengaruhi loyalitas konsumen Tolak Angin. Berbicara mengenai identifikasi sosial pada hakekatnya masyarakat Indonesia termasuk dalam collective orientes values. Hawkins et.al (2007:46) menyatakan konsumen dari negara yang lebih kolektif cenderung imitatif dalam melakukan pembelian. Hal ini menunjukan bahwa konsumen di Indonesia memiliki kecenderungan perilaku komformitas sendiri. Perilaku untuk hidup berkelompok dan memiliki keinginan untuk diakui sebagai anggota kelompok (komunal) atas eksistensi dirinya menyebabkan seseorang atau konsumen dalam hal ini, akan cenderung beradaptasi, menyesuaikan dengan perilaku kelompok. Perilaku sosial semacam ini mengarahkan konsumen untuk berperilaku sesuai dengan kecenderungan perilaku kelompok sosial dimana konsumen tersebut berinteraksi. Pendapat ini dukung oleh del Rio et.al (2001) yang menyatakan bahwa fakta mengenai asosiasi merek sebagai identifikasi sosial adalah berdasar pada kemampuan merek sebagai instrumen komunikasi. 
Dari hasil pengujian dapat diketahui bahwa variabel asosiasi merek sebagai identifikasi personal berpengaruh pada kesediaan konsumen untuk membayar dengan harga premium dan merekomendasikan ke orang lain. Dari hasil analisa juga diketahui bahwa asosiasi merek sebagai identifikasi personal juga mulai terbentuk pada ingatan konsumen Tolak Angin. Ini berarti bahwa merek Tolak Angin mulai dapat dipakai sebagai cerminan identitas diri konsumennya.

Hal ini juga didukung dari hasil penelitian dilapangan dari responden Tolak Angin yang menunjukan rata rata responden memberikan skala yang tinggi untuk indikator Tolak Angin mencerminkan individu yang memiliki gaya hidup praktis dan yang memiliki gaya hidup modern. Para responden memberikan komentar bahwa mereka suka menggunakan merek Tolak Angin karena karena jamu Tolak Angin disajikan dalam bentuk sachet yang mudah dibawa kemana-mana dan yang jelas instan sesuai dengan gaya hidup moderen yang serba sibuk. Hal ini ditunjang oleh penyampaian pesan secara itensif melalui iklan yang menampilkan personifikasi orang-orang moderen jauh dari kesan tradisional, yang kemudian hal ini secara perlahan terkonstruksi dalam benak konsumen sehingga lahir kesan emosional yang menganggap bahwa produk jamu Tolak Angin sangat sesuai dengan gaya hidup modern. Westbrook , 1987 seperti yang dikutip del Rio et.al (2001) menyatakan bahwa konsumen yang mengasosiasikan merek dengan pengalaman emosional memiliki kecenderung untuk merekomendasikan merek kepada pihak lain. Semakin tinggi ketertarikan dan identifikasi personal konsumen terhadap merek maka semakin tinggi motivasinya untuk merekomendasikan merek tersebut, berpengaruh positif untuk menerima ekstensi merek dan menerima harga premium.

Dari hasil pengujian dapat diketahui bahwa variabel asosiasi merek sebagai identifikasi sosial berpengaruh pada kesediaan konsumen untuk membayar dengan harga premium dan merekomendasikan ke orang lain. Ini berarti bahwa lingkungan sosial mempengaruhi loyalitas konsumen Tolak Angin. Berbicara mengenai identifikasi sosial pada hakekatnya masyarakat Indonesia termasuk dalam collective orientes values. Hawkins et.al (2007:46) menyatakan konsumen dari negara yang lebih kolektif cenderung imitatif dalam melakukan pembelian. Hal ini menunjukan bahwa konsumen di Indonesia memiliki kecenderungan perilaku komformitas sendiri. Perilaku untuk hidup berkelompok dan memiliki keinginan untuk diakui sebagai anggota kelompok (komunal) atas eksistensi dirinya menyebabkan seseorang atau konsumen dalam hal ini, akan cenderung beradaptasi, menyesuaikan dengan perilaku kelompok. Perilaku sosial semacam ini mengarahkan konsumen untuk berperilaku sesuai dengan kecenderungan perilaku kelompok sosial dimana konsumen tersebut berinteraksi. Pendapat ini dukung oleh del Rio et.al (2001) yang menyatakan bahwa fakta mengenai asosiasi merek sebagai identifikasi sosial adalah berdasar pada kemampuan merek sebagai instrumen komunikasi. Instrumen tersebut memberikan kesempatan bagi konsumen untuk mewujudkan keinginan untuk berinteraksi atau melepaskan diri dari kelompok individu yang menggunakan suatu merek. Konsumen yang merasa bahwa merek mempunyai reputasi baik dan dibeli oleh banyak orang, akan bersedia membayar harga premium dan menerima ektensi merek (Aaker,1991; Hutton,1997). Dan dari hasil pengujian juga diketahui bahwa variabel asosiasi merek sebagai status mempunyai pengaruh yang paling tinggi pada kesediaan membayar dengan harga premium dan kemauan untuk merekomendasikan ke orang lain. Ini berarti bahwa usaha produsen Tolak Angin dalam mengkomunikasikan melalui tagline orang pintar minum Tolak Angin dan penggunaan endorser endorser yang mencerminkan orang sukses dalam bidangnya mampu membentuk asosiasi merek sebagai status pada konsumen Tolak Angin. Kotler dan Keller (2006) 
menjelaskan bahwa tiap orang tergabung dalam banyak kelompok keluarga, klub, atau organisasi. Posisi seseorang dalam kelompok merupakan peran dan status. Merek yang disukai konsumen menunjukan indikasi status konsumen yang bersangkutan (Longman, 2007). Hal ini relevan dengan pandangan yang menyatakan bahwa asosasi merek sebagai status merupakan asosiasi konsumen yang berhubungan ekspresi bangga atau gengsi saat menggunakan merek. Peran meliputi aktifitas aktifitas yang diharapkan dari seseorang dan tiap peran membawa sebuah status. Merek yang dibeli konsumen akan menunjukan siapa konsumen tersebut. Konsumen merasakan pengalaman itu akan rekomendasi merek dan mau membayar dengan harga premium (Park et.al,.1991 dalam Del Rio et.al., 2001)

\section{KESIMPULAN}

Berdasarkan pengujian hipotesis yang dilakukan pada penelitian ini, maka dapat disimpulkan bahwa variabel asosiasi merek sebagai garansi, identifikasi personal, identifikasi sosial, dan status berpengaruh pada variabel respon konsumen berupa kesediaan konsumen Tolak Angin di Surabaya untuk merekomendasikan merek serta membayar dengan harga premium. Saran yang diharapkan dapat bermanfaat dalam melaksanakan kegiatan pemasaran khususnya dalam menciptakan dan memelihara asosiasi merek sehingga konsumen bersedia untuk membayar dengan harga premium, menerima perluasan merek dan merekomendasikan kepada pihak lain. Produsen jamu Tolak Angin lebih meningkatkan asosiasi merek para konsumennya dengan mengangkat tema tema yang lebih inovatif, dengan maksud agar para konsumennya merasakan kesamaan karakteristik antara merek Tolak Angin dengan karakteristik dirinya. Produsen jamu Tolak Angin perlu mempertahankan agar asosiasi akan jaminan kualitas tetap dirasakan para konsumen Tolak Angin, dan bahkan lebih ditingkatkan lagi. Tujuannya agar citra Tolak Angin sebagai produk higienis dan herbal dan citra PT. Sido Muncul sebagai produsen jamu dengan teknologi modern tertanam dalam benak konsumennya.

Dari hasil penelitian didapatkan korelasi yang tinggi antara variabel dependen dengan variabel kanonikalnya, untuk itu pada penelitian mendatang analisis akan lebih relevan jika dijelaskan dengan menggunakan model regresi. Hal ini sekaligus menunjukan keterbatasan penelitian ini untuk tidak menggunakan 2 variabel dependen respon konsumen karena memiliki korelasi yang tinggi Agar hasil hasil penelitian dapat digeneralisasikan, maka peneliti berikutnya mengembangkan model penelitian yang lebih baik dan memperluas jumlah sampel yang diambil dari lokasi penelitian.

\section{DAFTAR PUSTAKA}

Aaker, D.A. 1991. Managing Brand Equity - Capitalizing on the Value of a Brand Name. The Free Press.New York.

Aaker, D.A. 1996. Measuring Brand Equity Across Products and Markets. California Management Review.Spring 1996; 38, 3; ABI/INFORM Global pg. 102

Aaker, D.A. 1996. Building Strong Brand. The Free Press. New York.

Del Rio, Belen, A., Vasquez, R., \& Iglesias, V. 2001. The Effects of Brand Associations on Consumer Response. The Journal of Consumer Marketing. Vol 28 No. 52001.

Durianto, D., Sugiarto \& Sitinjak,T. 2001. Strategi Menaklukan Pasar Melalui Riset Ekuitas dan Perilaku Merek. PT. Gramedia Pustaka Utama. Jakarta.

Durianto, D. 2005. Membangun Merek Kuat. www.swa.co.id

Hawkins, D.I., Mothersbaugh, D.L \& Best, R.J. 2007. Consumer Behavior New York: The Mc Graw Hill Companies Inc.

Hutton, J.G. 1997. A Study Of Brand Equity In An Organizational-Buying Context. The Journal of Product 
and Brand Management. Santa Barbara: 1997. Vol.6, Iss. 6; pg. 428

Keller, K.L. 1993. Conceptualizing, Measuring, and Managing CustomerBase Brand Equity. Journal of Marketing. Vol 57.

Kotler, P \& Keller, K.L 2006. Marketing Management. New Jersey: Pearson Education, Inc.

Pettis, C.1995. Technobrands: How To Create And Use Brand Identity To Market Advertise and Sell Technology Products. New York: American Management Association,

Powpaka, S. 1993. Consumer Response to
Brand Equity.UMI Number 932849.

Rangkuti, F. 2002. The Power of Brands, Teknik Mengelola Brand Equity dan Strategy Pengembangan Merek. Analisis Kasus dengan SPSS . PT. Gramedia Pustaka Utama. p.42. Jakarta

Ross, S.D. 2003. The Development of a Scale to Measure Professional Sport Team Brand Associations. UMI Number 3101959

Zainudin, M. 1999. Metodologi Penelitian. (Diklat Kuliah Program Magister Manajemen Universitas Airlangga). 